\title{
Amino acid concentration, total phenolic compound content and antioxidant activity of snap bean genotypes
}

\author{
Concentração de aminoácidos, conteúdo de fenólicos totais e \\ atividade antioxidante em genótipos de feijão-vagem
}

Anderson Yusei Suzuki Fukuji', Leonel Vinicius Constantino', Douglas Mariani Zeffa ${ }^{2 *}$ (D), Felipe Aranha de Andrade ${ }^{1}$, Mayara Barbosa da Silva ${ }^{2}$, Leandro Simões Azeredo Gonçalves ${ }^{1}$

${ }^{1}$ Universidade Estadual de Londrina (UEL), Departamento de Agronomia, Londrina/PR - Brasil

${ }^{2}$ Universidade Estadual de Maringá (UEM), Departamento de Agronomia, Maringá/PR - Brasil

*Corresponding author: Douglas Mariani Zeffa, Universidade Estadual de Maringá (UEM), Departamento de Agronomia, Av. Colombo, 5790, Zona 7, CEP: 87020-900, Maringá/PR - Brasil, e-mail: douglas.mz@hotmail.com

Cite as: Fukuji, A. Y. S., Constantino, L. V., Zeffa, D. M., Andrade, F. A., Silva, M. B., \& Gonçalves, L. S. A. (2019).

\begin{abstract}
The snap bean (Phaseolus vulgaris L.) is an economically important legume worldwide due to its good nutritional quality, being considered as a source of protein, fibre, vitamins and minerals. Furthermore, snap beans present high phenolic compound levels and antioxidant activity, factors that contribute in the prevention of the oxidation effects by free radicals. Hence, the present study characterized five snap bean genotypes (UEL 1, UEL 2, UEL 405, UEL 415 and Alessa) with respect to their amino acid concentrations, total phenolic compound contents and antioxidant activities. The amino acid analysis indicated that UEL 415 showed the highest glutamic acid content $(12.9 \mathrm{~g} / 100 \mathrm{~g})$ and UEL 2 the highest histidine content $(2.27 \mathrm{~g} / 100 \mathrm{~g})$. However, only the UEL 1 genotype showed the highest total phenolic compound content $(0.492 \mathrm{mg} \mathrm{GAE} / 100 \mathrm{~g})$ and highest antioxidant activity according to $\mathrm{DPPH} \cdot$ radical scavenging (64.71\%). The UEL 1, UEL 2 and UEL 415 genotypes presented desirable chemical characteristics for genetic improvement programmes and their commercial exploitation by food industries.
\end{abstract}

Keywords: Phaseolus vulgaris L.; Protein quality; Nutritional profile; Free radicals; Legume; DPPH method.

\section{Resumo}

O feijão-vagem (Phaseolus vulgaris L.) é uma leguminosa economicamente importante em todo o mundo, devido à sua boa qualidade nutricional, considerada fonte de proteínas, fibras, vitaminas e minerais. Além disso, esta hortaliça apresenta altos níveis de compostos fenólicos e atividade antioxidante, fatores que contribuem para a prevenção contra os efeitos de oxidação por radicais livres. Assim, o presente estudo caracterizou cinco genótipos de feijãovagem (UEL 1, UEL 2, UEL 405, UEL 415 e Alessa) em relação à concentração de aminoácidos, ao teor de compostos fenólicos totais e à atividade antioxidante. A análise de aminoácidos indicou que os genótipos UEL 415 e UEL 2 apresentaram as maiores concentrações de ácido glutâmico e histidina, com 12,9 e 2,27 g/ $100 \mathrm{~g}$, respectivamente. No entanto, apenas o genótipo UEL 1 apresentou as maiores concentrações de compostos fenólicos totais (0,492 mg GAE / 100 g) e a capacidade antioxidante por captura de radicais DPPH• (64,71\%). Os genótipos UEL 1, 
UEL 2 e UEL 415 apresentaram características desejáveis para o programa de melhoramento genético de feijão e exploração comercial por indústrias de alimentos.

Palavras-chave: Phaseolus vulgaris L.; Proteínas; Compostos bioativos; Hortaliça; Radicais livres; Método DPPH.

\section{Introduction}

Snap bean (Phaseolus vulgaris L.) is an economically important legume available worldwide, also known as green beans, which may be harvested for fresh consumption, freezing or canning (Prohens \& Nuez, 2008). Snap beans have great nutritional quality, considered as a source of fibre, vitamins, minerals and mainly of protein, which is one of the most important components of the human diet. It also contains antioxidant substances that promote beneficial health effects (Baardseth et al., 2010).

Legumes, such as beans, soybeans, peas, lentils, peanuts and other pod plants have played an important role in the traditional diets of many countries, besides constituting an excellent source of protein (Sgarbieri et al., 1979; Messina, 1999). The nutritive value of snap bean proteins depends mainly on their free amino acid content, of which leucine and glutamic acid should be highlighted due to the high levels found in beans and other legumes (Sgarbieri et al., 1979; Gonzalez-Castro et al., 1997; Tessari et al., 2016).

Studies have reported a correlation between vegetable consumption and decreases in the risk of cardiovascular diseases and some forms of cancer, due to the antioxidant activity of the bioactive compounds. The antioxidant substances present in vegetables can aid in the prevention, protection against and delay in oxidation that makes free radicals inactive, playing an important role in the human defence system against reactive oxygen species (ROS) (Devasagayam et al., 2004; Dauchet et al., 2006).

Of the bioactive phytocompounds with antioxidant properties found in foods, the phenolic compounds should be highlighted due to their contribution to human health (Boffetta et al., 2010; Haminiuk et al., 2012). The aim of this study was focused on the determination of the free amino acids, the total phenolic compound content and the antioxidant activity in snap bean genotypes, since higher levels of amino acids, total phenolic compounds and antioxidant activity in snap beans contribute to the selection of genotypes with desirable nutritional attributes for genetic improvement programmes and commercial exploitation.

\section{Material and methods}

The amino acid composition, total phenolic compound content and antioxidant activity were quantified in five snap bean genotypes with determinate growth habits: four from the genetic improvement programme at the State University of Londrina, Brazil (UEL 1, UEL 2, UEL 405 and UEL 415) and the other a commercial cultivar (Alessa).

A completely randomized experimental design was used with three replicates and the experiment was carried out during the months from April to June 2014 at the Farm School of the State University of Londrina $\left(23^{\circ} 20^{\prime} 23^{\prime} \mathrm{S}, 51^{\circ} 12^{\prime} 32^{\prime} \mathrm{W}, 535 \mathrm{~m}\right.$ altitude) in an area under organic management for the past five years.

A chemical analysis of the soil showed the following values: $\mathrm{pH}\left(\mathrm{H}_{2} \mathrm{O}\right)=5.5 ; \mathrm{P}=3.41 \mathrm{cmolc}^{-3}$; $\mathrm{K}^{+}=0.74 \mathrm{cmolc} \mathrm{dm}^{-3} ; \mathrm{Ca}^{+2}=6.8 \mathrm{cmolc} \mathrm{dm}{ }^{-3} ; \mathrm{Mg}^{+2}=1.2 \mathrm{cmolc} \mathrm{dm}^{-3} ; \mathrm{Al}^{+3}=0.05 \mathrm{cmolc} \mathrm{dm}^{-3} ; \mathrm{H}$ and $\mathrm{Al}=4.28 \mathrm{cmolc} \mathrm{dm}^{-3} ; \mathrm{CEC}=13.02 \mathrm{cmolc} \mathrm{dm}{ }^{-3} ; \mathrm{V}=67.13 \%$ and $\mathrm{OM}=1.87 \mathrm{dag} \mathrm{kg}^{-1}$. The soil management of the area used $10 \mathrm{tha}^{-1}$ of organic compound with the following chemical composition: $\mathrm{pH}\left(\mathrm{H}_{2} \mathrm{O}\right)=7.2$; $\mathrm{P}=359.30 \mathrm{mg} \mathrm{dm}{ }^{-3} ; \mathrm{K}^{+}=5.78 \mathrm{cmolc} \mathrm{dm}{ }^{-3} ; \mathrm{Ca}^{+2}=9.5 \mathrm{cmolc} \mathrm{dm}^{-3} ; \mathrm{Mg}^{+2}=6.9 \mathrm{cmolc} \mathrm{dm}^{-3} ;$ $\mathrm{Al}^{+3}=0.0 \mathrm{cmolc} \mathrm{dm}^{-3} ; \mathrm{H}$ and $\mathrm{Al}=2.19 \mathrm{cmolc} \mathrm{dm}^{-3} ; \mathrm{CEC}=24.37 \mathrm{cmolc} \mathrm{dm}^{-3} ; \mathrm{V}=91.01 \%$ and $\mathrm{OM}=5.5 \mathrm{dag} \mathrm{kg}^{-1}$. An aspersion irrigation system was used to water the crop and weed control was carried out by laying straw between the lines throughout the area. Bordeaux mixture $(0.5 \%)$ was applied before flowering for disease control. 
Ten pods were collected from each plot for analysis, which were freeze-dried (Christ Alpha 2-4 LD plus, Germany), ground using a knife grinder (Ika, 33), and stored at $-26{ }^{\circ} \mathrm{C}$ until analysed. The amino acids were quantified by ion exchange chromatography with post-column derivation using ninhydrin, according to Spackman et al. (1963). The extracts used to determine the phenolic compound content and antioxidant activity were obtained from $0.100 \mathrm{~g}$ freeze-dried pods using $10 \mathrm{~mL}$ of $80 \%$ ethanol $(\mathrm{v} / \mathrm{v})$, shaking at $200 \mathrm{rpm}$ for $20 \mathrm{~min}$ at $25^{\circ} \mathrm{C}$. The suspension was centrifuged at $2500 \times \mathrm{g}$ (Fanem, Excelsa 3 Model 280, Brazil) and the supernatant separated for analysis.

The total phenolic compound content was determined using $1.0 \mathrm{~mL}$ of the diluted ethanolic extract and adding $1.0 \mathrm{~mL}$ of $0.90 \mathrm{~N}$ Folin-Ciocalteau reagent and $1.0 \mathrm{~mL}$ of $10 \%(\mathrm{w} / \mathrm{v})$ sodium carbonate solution. The mixture was incubated for $30 \mathrm{~min}$ in the dark at $25^{\circ} \mathrm{C}$ and the absorbance then measured at $760 \mathrm{~nm}$ in a spectrophotometer (Agillent 8453) using gallic acid as the standard for quantification. The results were expressed as mg gallic acid equivalents (GAE) per $100 \mathrm{~g}$ dry weight (Singleton et al., 1999).

The antioxidant activity was quantified based on Turkmen et al. (2005) using a $1.5 \mathrm{~mL}$ aliquot of $0.10 \mathrm{mM}$ $\mathrm{DPPH} \cdot$ radical in methanol, added to a test tube containing $0.5 \mathrm{~mL}$ of the sample extract. The tubes were shaken and left to stand at $25^{\circ} \mathrm{C}$ in the dark for $60 \mathrm{~min}$. The absorbance (Abs) was then measured at $517 \mathrm{~nm}$. The antioxidant activity (AA) was calculated according to the ability to scavenge the DPPH radical using the following equation (1): $A A(\%)=\left[\frac{\left(A b s_{\text {control }}-A b s_{\text {sample }}\right)}{A b s_{\text {control }}}\right] \times 100$

The analysis of variance (ANOVA) was used for the data analysis and the means compared by Tukey's test $(p<0.05)$, using the $\mathrm{R}$ software ( $\mathrm{R}$ Core Team, 2018).

\section{Results and discussion}

In general, the concentrations of the amino acids in the genotypes did not differ significantly, except for glutamic acid and histidine (Table 1). High contents of aspartic acid and leucine were also observed in all the snap bean genotypes, agreeing with the data of Sgarbieri et al. (1979) and of Tessari et al. (2016), who found values that ranged from 13.8 to $14.5 \mathrm{~g} / 100 \mathrm{~g}$ for aspartic acid and from 8.85 to $9.94 \mathrm{~g} / 100 \mathrm{~g}$ for leucine, similar concentrations to those found in the present study.

Table 1. Amino acid compositions and concentrations in the five snap bean genotypes.

\begin{tabular}{|c|c|c|c|c|c|c|}
\hline \multirow{2}{*}{ Amino acids } & UEL 405 & UEL 415 & UEL 1 & UEL 2 & Alessa & \multirow{2}{*}{ CV (\%) } \\
\hline & \multicolumn{5}{|c|}{$\left(\mathrm{g} 100 \mathrm{~g}^{-1} \text { protein }\right)^{\mathrm{a}}$} & \\
\hline Alanine & $6.42 \pm 0.38$ & $6.08 \pm 0.04$ & $6.51 \pm 0.08$ & $6.25 \pm 0.23$ & $6.02 \pm 0.11$ & 3.35 \\
\hline Arginine & $5.37 \pm 1.10$ & $4.51 \pm 0.29$ & $4.85 \pm 0.05$ & $4.86 \pm 0.15$ & $4.71 \pm 0.12$ & 9.59 \\
\hline Aspartic acid & $12.6 \pm 1.20$ & $13.7 \pm 0.04$ & $11.8 \pm 0.46$ & $12.1 \pm 0.45$ & $13.2 \pm 0.44$ & 5.03 \\
\hline Cystine & 0 & 0 & 0 & 0 & 0 & - \\
\hline Glutamic acid & $10.9 \pm 0.26 \mathrm{~b}$ & $12.9 \pm 0.16 \mathrm{a}$ & $10.8 \pm 0.13 b$ & $11.8 \pm 0.54 \mathrm{ab}$ & $11.9 \pm 0.05 \mathrm{ab}$ & 2.43 \\
\hline Glycine & $3.71 \pm 0.59$ & $3.84 \pm 0.07$ & $4.51 \pm 0.06$ & $3.91 \pm 0.08$ & $3.89 \pm 0.10$ & 6.85 \\
\hline Histidine & $1.67 \pm 0.30 \mathrm{~b}$ & $2.11 \pm 0.05 \mathrm{ab}$ & $2.13 \pm 0.03 \mathrm{ab}$ & $2.27 \pm 0.04 \mathrm{a}$ & $1.91 \pm 0.06 \mathrm{ab}$ & 6.88 \\
\hline Isoleucine & $4.40 \pm 0.42$ & $4.98 \pm 0.04$ & $5.20 \pm 0.20$ & $5.06 \pm 0.49$ & $5.24 \pm 0.00$ & 6.09 \\
\hline Leucine & $10.6 \pm 0.11$ & $10.27 \pm 0.04$ & $11.02 \pm 0.40$ & $10.2 \pm 0.96$ & $10.9 \pm 0.13$ & 4.47 \\
\hline Lysine & $7.21 \pm 1.16$ & $8.06 \pm 0.30$ & $8.18 \pm 0.33$ & $8.79 \pm 0.46$ & $8.35 \pm 0.04$ & 8.27 \\
\hline Methionine & $2.04 \pm 0.11$ & $2.24 \pm 0.10$ & $2.51 \pm 0.07$ & $2.06 \pm 0.39$ & $2.19 \pm 0.11$ & 8.83 \\
\hline Phenylalanine & $7.44 \pm 0.94$ & $6.00 \pm 0.26$ & $6.43 \pm 0.27$ & $6.04 \pm 0.08$ & $6.17 \pm 0.08$ & 5.78 \\
\hline Proline & $7.78 \pm 0.04$ & $7.35 \pm 0.31$ & $7.88 \pm 0.45$ & $7.49 \pm 0.63$ & $7.67 \pm 0.44$ & 5.51 \\
\hline Serine & $4.82 \pm 0.01$ & $4.35 \pm 0.03$ & $3.80 \pm 0.07$ & $4.25 \pm 0.58$ & $4.00 \pm 0.05$ & 6.19 \\
\hline Threonine & $3.95 \pm 0.41$ & $3.56 \pm 0.07$ & $3.42 \pm 0.10$ & $3.61 \pm 0.17$ & $3.44 \pm 0.11$ & 5.89 \\
\hline Tyrosine & $3.42 \pm 0.71$ & $3.58 \pm 0.16$ & $3.90 \pm 0.07$ & $4.83 \pm 0.92$ & $3.89 \pm 0.02$ & 9.41 \\
\hline Valine & $7.80 \pm 1.80$ & $6.55 \pm 0.18$ & $7.11 \pm 0.04$ & $6.57 \pm 0.06$ & $6.63 \pm 0.23$ & 9.79 \\
\hline
\end{tabular}

${ }^{a}$ Means followed by the same letters do not differ according to Tukey's test $(p<0.05)$. 
The UEL 415 genotype showed a higher glutamic acid concentration ( $12.9 \mathrm{~g} / 100 \mathrm{~g})$ than the UEL 405 $(10.9 \mathrm{~g} / 100 \mathrm{~g})$ and UEL $1(10.8 \mathrm{~g} / 100 \mathrm{~g})$ genotypes, while the UEL 2 genotype had a higher concentration of histidine as compared to UEL 405 (2.13 and $1.67 \mathrm{~g} / 100 \mathrm{~g}$, respectively). Sgarbieri et al. (1979) found a range from 18.32 to $20.74 \mathrm{~g} / 100 \mathrm{~g}$ for histidine and from 2.33 to $2.94 \mathrm{~g} / 100 \mathrm{~g}$ for glutamic acid in four common bean genotypes. These values were higher than those obtained for the snap beans in the current study, probably due to the vegetable material used. In the present work, the amino acid concentrations were determined in the pods, while Sgarbieri et al. (1979) used the beans.

Freeze dried snap beans obtained from a commercial plantation in Spain presented glutamic acid and histidine concentrations of 1.65 and $0.340 \mathrm{~g} / 100 \mathrm{~g}$ dry weight, respectively (Gonzalez-Castro et al., 1997). Cysteine was not detected in the present study due to its rapid oxidation to cysteic acid. The amino acids levels found in the genotypes analysed were approximately ten times higher than those found by GonzalezCastro et al. (1997), indicating a greater nutritional quality of these snap bean genotypes, mainly of UEL 2 and UEL 415.

The total phenolic compound contents of the genotypes ranged from 0.310 to $0.492 \mathrm{mg} \mathrm{GAE} / 100 \mathrm{~g}$. The UEL 1 genotype also showed a high content of total phenolic compounds (Figure 1a). Marinova et al. (2005) compared the total phenolic compound contents of 22 vegetables and found $0.035 \mathrm{mg}$ GAE / $100 \mathrm{~g}$ for snap beans, while Baardseth et al. (2010) found $0.21 \mathrm{mg} \mathrm{GAE} / 100 \mathrm{~g}$ and Jiratanan \& Liu (2004) $0.80 \mathrm{mg}$ GAE / $100 \mathrm{~g}$. Hence, the genotypes UEL 1 and UEL 2 showed great potential for a genetic improvement programme aimed at the canned food industry. Phenolic compounds are related to the antioxidant activity of the food and the prevention of several diseases (Haminiuk et al., 2012). Vinson et al. (1998) determined the total phenolic compound content in 23 vegetables and ranked snap beans in $16^{\text {th }}$ position, and Marinova et al. (2005), quantified the total phenolic compound content of 22 vegetables, including snap beans. Thus genetic improvement programmes could select genotypes with high contents for this attribute, as in the case of the UEL 1 and UEL 2 genotypes.

The greatest antioxidant activity was found for the genotype UEL 1 with $64.71 \%$ DPPH radical scavenging, followed by UEL 2 and UEL 415 with 51.5 and 39.25\%, respectively (Figure 1b). Zhou \& Yu (2006) determined the antioxidant activity of two snap bean genotypes, which showed similar antioxidant activity values of $60 \%$ remaining DPPH.
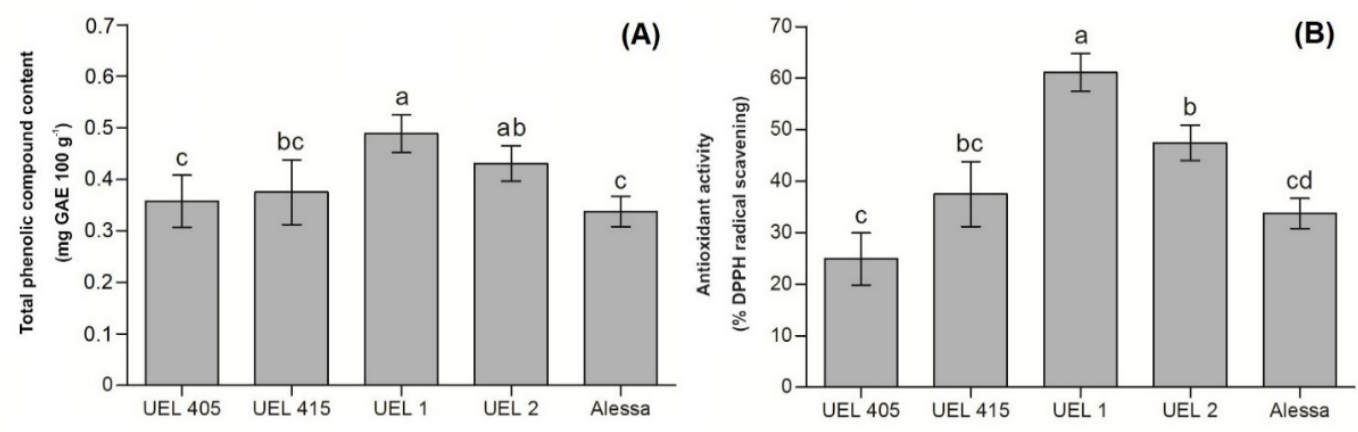

Figure 1. (A) Total phenolic compound content and (B) antioxidant activity of five snap bean genotypes. Means followed by the same letters do not differ according to Tukey's test $(p<0.05)$.

Kaur \& Kapoor (2002) verified three groups formed by 22 vegetables in relation to antioxidant activity: high antioxidant activity (> 70\%), including turmeric, broccoli, mint, beetroot, carrots, ginger, coriander, yam and tomato; moderate antioxidant activity ( $60 \%$ to $70 \%)$ represented by palak, cabbage, bell-pepper, carrots, carrot leaves, mustard, bathua, pea pods, potatoes and garlic; and low antioxidant activity $(<60 \%)$ including pea, onion, green chillies, snap beans, round melon, cauliflower and radish. The present study is in agreement with the ranges cited by these authors, with positive prominence for the genotypes UEL 1 and 
UEL 2, indicating the possibility for exploitation by the food industries, since consumption of these snap beans would contribute to the health, providing protective action attributed to the presence of antioxidants such as phenolic compounds.

\section{Conclusions}

The concentrations of the amino acids did not differ amongst the genotypes with the exception of histidine and glutamic acid, for which UEL 415 showed the highest values for glutamic acid and UEL 2 for histidine, indicating an interesting protein profile. Higher levels of total phenolic compound contents and antioxidant activity were found for the genotype UEL 1. Thus, the genotypes UEL 1, UEL 2 and UEL 415 presented desirable nutritional characteristics for use in genetic improvement programs aimed at commercial exploitation by food industries.

\section{Acknowledgements}

The authors would like to thank the Fundação Araucária of Paraná State (Brazil) for its financial support.

\section{References}

Baardseth, P., Bjerke, F., Martinsen, B. K., \& Skrede, G. (2010). Vitamin C, total phenolics and antioxidative activity in tip-cut green beans (Phaseolus vulgaris) and swede rods (Brassica napus var. napobrassica) processed by methods used in catering. Journal of the Science of Food and Agriculture, 90(7), 1245-1255. PMid:20394008. http://dx.doi.org/10.1002/jsfa.3967

Boffetta, P., Couto, E., Wichmann, J., Ferrari, P., Trichopoulos, D., Bueno-de-Mesquita, H. B., van Duijnhoven, F. J., Büchner, F. L., Key, T., Boeing, H., Nöthlings, U., Linseisen, J., Gonzalez, C. A., Overvad, K., Nielsen, M. R., Tjønneland, A., Olsen, A., Clavel-Chapelon, F., Boutron-Ruault, M. C., Morois, S., Lagiou, P., Naska, A., Benetou, V., Kaaks, R., Rohrmann, S., Panico, S., Sieri, S., Vineis, P., Palli, D., van Gils, C. H., Peeters, P. H., Lund, E., Brustad, M., Engeset, D., Huerta, J. M., Rodríguez, L., Sánchez, M. J., Dorronsoro, M., Barricarte, A., Hallmans, G., Johansson, I., Manjer, J., Sonestedt, E., Allen, N. E., Bingham, S. Khaw, K. T., Slimani, N., Jenab, M., Mouw, T., Norat, T., Riboli, E., \& Trichopoulou, A. (2010). Fruit and vegetable intake and overall cancer risk in the European Prospective Investigation into Cancer and Nutrition (EPIC). Journal of the National Cancer Institute, 102(8), 529-537. PMid:20371762. http://dx.doi.org/10.1093/jnci/djq072

Dauchet, L., Amouyel, P., Hercberg, S., \& Dallongeville, J. (2006). Fruit and vegetable consumption and risk of coronary heart disease: A meta-analysis of cohort studies. The Journal of Nutrition, 136(10), 2588-2593. PMid:16988131. http://dx.doi.org/10.1093/jn/136.10.2588

Devasagayam, T. P., Tilak, J. C., Boloor, K. K., Sane, K. S., Ghaskadbi, S. S., \& Lele, R. D. (2004). Free radicals and antioxidants in human health: current status and future prospects. The Journal of the Association of Physicians of India, 52, 794804. PMid:15909857.

Gonzalez-Castro, M. J., Lopez-Hernández, J., Simal-Lozano, J., \& Oruna-Concha, M. J. (1997). ORUÑA-CONCHA., M.J. Determination of Amino Acids in Green Beans by Derivatization with Phenylisothiocianate and High-Performance Liquid Chromatography with Ultraviolet Detection. Journal of Chromatographic Science, 35(4), 181-185. http://dx.doi.org/10.1093/chromsci/35.4.181

Haminiuk, C. W., Maciel, G. M., Plata-Oviedo, M. S. V., \& Peralta, R. M. (2012). Phenolic compounds in fruits - an overview. International Journal of Food Science \& Technology, 47(10), 2023-2044. http://dx.doi.org/10.1111/j.1365-2621.2012.03067.x

Jiratanan, T., \& Liu, R. H. (2004). Antioxidant activity of processed table beets (Beta vulgaris var. conditiva) and green beans (Phaseolus vulgaris L.). Journal of Agricultural and Food Chemistry, 52(9), 2659-2670. PMid:15113174. http://dx.doi.org/10.1021/jf034861d

Kaur, C., \& Kapoor, H. C. (2002). Anti-oxidant activity and total phenolic content of some Asian vegetables. International Journal of Food Science \& Technology, 37(2), 153-161. http://dx.doi.org/10.1046/j.1365-2621.2002.00552.x

Marinova, D., Ribarova, F., \& Atanassova, M. (2005). Total phenolics and total flavonoids in Bulgarian fruits and vegetables. Journal University Chemical Technological Metallurgy, 40, 255-260.

Messina, M. J. (1999). Legumes and soybeans: overview of their nutritional profiles and health effects. The American Journal of Clinical Nutrition, 70(3, Supl.), 439-450. PMid:10479216. http://dx.doi.org/10.1093/ajcn/70.3.439s

Prohens, J., \& Nuez, F. (2008). Handbook of Plant Breeding. Vegetables II: Fabaceae, Liliaceae, Solanaceae and Umbelliferae (2. ed., 365 pp.). New York: Springer Science.

R Core Team (2018). R: A language and environment for statistical computing. Vienna: R Foundation for Statistical Computing Retrieved in 2018, March 23, from https://www.R-project.org

Sgarbieri, V. C., Antunes, P. L., \& Almeida, L. D. (1979). Nutrional evaluation of four varieties of dry beans (Phaseolus vulgaris L.). Journal of Food Science, 44(5), 1306-1308. http://dx.doi.org/10.1111/j.1365-2621.1979.tb06425.x 
Singleton, V. L., Orthofer, R., \& Lamuela-Raventos, R. M. (1999). Analysis of total phenols and other oxidation substrates and antioxidants by means of Folin-Ciocalteu reagent. Methods Enzymological, 299, 152-178. http://dx.doi.org/10.1016/S00766879(99)99017-1

Spackman, D. H., Stein, W. H., \& Moore, S. (1963). Automatic recording apparatus for use in the chromatography of amino acids. Analytical Chemistry, 30(7), 1190-1206. http://dx.doi.org/10.1021/ac60139a006

Tessari, P., Lante, A., \& Mosca, G. (2016). Essential amino acids: master regulators of nutrition and environmental footprint? Scientific Reports, 6(1), 26074. PMid:27221394. http://dx.doi.org/10.1038/srep26074

Turkmen, N., Sari, F., \& Velioglu, Y. S. (2005). The effect of cooking methods on total phenolics and antioxidant activity of selected green vegetables. Food Chemistry, 93(4), 713-718. http://dx.doi.org/10.1016/j.foodchem.2004.12.038

Vinson, J. A., Hao, Y., Su, X., \& Zubik, L. (1998). Phenol antioxidant quantity and quality in foods: Vegetables. Journal of Agricultural and Food Chemistry, 46(9), 3630-3634. http://dx.doi.org/10.1021/jf980295o

Zhou, K., \& Yu, L. (2006). Total phenolic contents and antioxidant properties of commonly consumed vegetables grown in Colorado. Food Science and Technology, 39, 1155-1162. 